\title{
Comparison of ultrasonography and skinfold measurements of subcutaneous fat thickness in the evaluation of body composition
}

\author{
Şahika Pınar Akyer ${ }^{1}$, Esat Adıgüzel ${ }^{1}$, Nuran Sabir ${ }^{2}$, Ilgaz Akdoğan ${ }^{1}$, Birsen Yılmaz ${ }^{3}$, Gökşin Nilüfer Yonguç ${ }^{4}$ \\ ${ }^{1}$ Department of Anatomy, Faculty of Medicine, Pamukkale University, Denizli, Turkey \\ ${ }^{2}$ Department of Radiology, Faculty of Medicine, Pamukkale University, Denizli, Turkey \\ ${ }^{3}$ Denizli Health Directorate, Denizli, Turkey \\ ${ }^{4}$ Department of Anatomy, Faculty of Medicine, Izmir University, Izmir, Turkey
}

\begin{abstract}
Objectives: To determine the amount of body fat tissue with skinfold thickness measurements is a common method to estimate the body composition. The other method used for this purpose is ultrasonography which is expensive and needs specialization to apply. In this study, validity of skinfold thickness measurements was investigated using ultrasonography.

Methods: One hundred adult volunteers (50 males and 50 females) were used in this study. The ages of the subjects were 20 to 70, selected as 10 males and 10 females for each decade. Subcutaneous fat thickness of the subjects were measured at seven body sites (submandibula, triceps, biceps, subscapula, suprailiac, thigh and calf) using a skinfold caliper and an ultrasound equipment. The measurements were made by the same person on the right side of the body, while the subject was standing in a upright position.
\end{abstract}

Results: Mean ultrasonographic measurements were smaller than those performed using a skinfold caliper at all areas $(p<0.05)$. Measurements performed with these two techniques were correlated significantly $(p<0.001)$ at submandibular $(r=$ 0.596), subscapular $(r=0.692)$, suprailiac $(r=0.706)$, triceps $(r=0.751)$, biceps $(r=0.752)$, thigh $(r=0.802)$ and calf $(r=0.849)$ areas.

Conclusion: The skinfold thickness measurements made using skinfold caliper provides reliable information about the subcutaneous fat tissue.

Keywords: body composition; skinfold thickness; subcutaneous fat

Anatomy 2014;8:2-6, @ 2014 TSACA

\section{Introduction}

According to the World Health Organization (WHO), anthropometry -compared to other procedures- is an inexpensive and harmless method for evaluating the size, proportions and composition of the human body. ${ }^{[1]}$ However, anthropometric methods are less sensitive compared to complex and technological techniques such as computerized tomography, magnetic resonance imaging or dual-energy X-ray absorptiometry. Nevertheless, because they are simple and inexpensive, anthropometric methods are still preferred for evaluating body composition, especially in studies conducted in large communi- ties. $^{[2]}$ Determining the reliability of these methods is vital for the effectiveness of these studies. ${ }^{[3]}$

Subcutaneous fat tissue comprises $50 \%$ of the total amount of body fat. Based on this fact, important information about body composition may be gained from the measurement of skinfold thickness. ${ }^{[4]}$ In some previous studies, ultrasonography (USG) was used for measuring the thickness of subcutaneous fat tissue, and it was reported as a method that provides accurate information on subcutaneous fat tissue thickness. ${ }^{[5-9]}$ Based on these conclusions, the subcutaneous fat tissue thickness measurements made with USG were accepted as reference 
values in our study, and the reliability of measurements with skinfold calipers was discussed.

\section{Materials and Methods}

One hundred (50 male, 50 female) participants aged 20-70 years were selected for the study, grouped as 10 male and 10 female participants for each 10 year. Consent was obtained from the participants who were informed about the aim of the study and procedures to be carried out. The height, weight and body mass index (BMI) of the participants are given in Table $\mathbf{1}$ for men and in Table 2 for women. Anthropometric and USG measurements were made at Pamukkale University Hospital, in the morning hours following 8-12 hour fasting period. Measurements were taken from the right side of the body with the participants standing in an upright positon with their clothes and shoes off. All measurements were performed by the same investigator.

Measurements of skinfold and subcutaneous fat tissue thickness were obtained from seven parts of the body using a skinfold caliper and an ultrasound device.

The sites from which measurements were taken were:

- Submandibular region: under the chin on the median plane $2 \mathrm{~cm}$ behind the gnathion

- Triceps: midpoint between the acromion and olecranon protrusions on the posterior center line of the arm

- Biceps: midpoint between the acromion and olecranon protrusions on the front center line of the arm

- Subscapular: 1-2 cm below the bottom end of the scapul

- Suprailiac: just above the intersection of the anterior axillary line with the anterior superior iliac spine

- Front thigh: midpoint of the imaginary line drawn between the upper edge of the patella and midpoint of inguinal ligament on the front of the thigh

Table 1

Height, weight and body mass index (BMI) of men in relatiom to age groups ( $n=10$ for each age group).

\begin{tabular}{lccc}
\hline Age ranges & $\begin{array}{c}\text { Height }(\mathbf{c m}) \\
\text { Mean } \pm \text { SD }\end{array}$ & $\begin{array}{c}\text { Weight }(\mathbf{k g}) \\
\text { Mean } \pm \text { SD }\end{array}$ & $\begin{array}{c}\text { BMI }\left(\mathbf{k g} / \mathbf{m}^{2}\right) \\
\text { Mean } \pm \text { SD }\end{array}$ \\
\hline $20-29$ & $179.3 \pm 8.4$ & $81.7 \pm 11.2$ & $25.4 \pm 2.8$ \\
$30-39$ & $173.1 \pm 8.0$ & $74.3 \pm 9.8$ & $24.8 \pm 3.0$ \\
$40-49$ & $170.8 \pm 5.3$ & $80.6 \pm 9.0$ & $27.6 \pm 2.5$ \\
$50-59$ & $170.3 \pm 5.7$ & $72.5 \pm 7.7$ & $25.0 \pm 2.8$ \\
$60-69$ & $167.7 \pm 5.4$ & $75.5 \pm 7.0$ & $26.8 \pm 1.9$ \\
\hline
\end{tabular}

- Inner surface of the calf: medial side of the thickest part of the calf

Holtain brand pincer type caliper was used to measure skinfold thickness. The skin and subcutaneous fat tissue was pinched with the thumb and forefinger, and lightly pulled away from the muscle tissue in alignment with the natural fold of skin for the measurements. The measurement included the double layer of skin and the subcutaneous fat tissue. At least two measures were made from each region and their average was calculated (Figure 1).

USG measurements were carried out using Logic 500 pro, General Electric, Milwaukee, WI, 6-9 MHz linear array ultrasound device. After placing the probe of the device perpendicular to the skin, the distance between the points where the skin joins the subcutaneous fat tissue, and the subcutaneous fat tissue joins muscle tissue was measured with an electronic caliper. The probe of the device was placed perpendicular to the skin, and the distance between the points where the skin was continuous with the subcutaneous fat tissue, and the subcutaneous fat tissue continuous with the muscle tissue was measured with an electronic caliper. Three measurements were obtained from each region and were averaged (Figure 2).

Data was analyzed using SPSS version 10.0 program (SPSS Inc., Chicago, IL, USA). For descriptive analysis the percentages, means and standard deviations were calculated. Paired sample t-tests were used for comparing anthropometric and USG measurements; independent t-test was used for the comparison of measurements for gender, and the relationship between skinfold measurements and USG measurements was evaluated with Pearson correlation analysis. $\mathrm{p}<0.05$ was accepted to be statistically significant.

\section{Results}

The skinfold thickness measurements performed with a skinfold caliper and subcutaneous fat tissue thickness val-

Table 2

Height, weight and body mass index (BMI) of women in relatiom to age groups ( $n=10$ for each age group).

\begin{tabular}{lccc}
\hline Age ranges & $\begin{array}{c}\text { Height }(\mathbf{c m}) \\
\text { Mean } \pm \text { SD }\end{array}$ & $\begin{array}{c}\text { Weight }(\mathbf{k g}) \\
\text { Mean } \pm \text { SD }\end{array}$ & $\begin{array}{c}\text { BMI }\left(\mathbf{k g} / \mathbf{m}^{2}\right) \\
\text { Mean } \pm \text { SD }\end{array}$ \\
\hline $20-29$ & $168.2 \pm 13.5$ & $68.5 \pm 17.6$ & $23.9 \pm 4.6$ \\
$30-39$ & $166.6 \pm 9.6$ & $68.5 \pm 12.5$ & $24.7 \pm 4.3$ \\
$40-49$ & $163.7 \pm 8.8$ & $72.4 \pm 11.6$ & $26.9 \pm 2.6$ \\
$50-59$ & $164.9 \pm 7.6$ & $70.9 \pm 9.6$ & $26.2 \pm 3.9$ \\
$60-69$ & $167.2 \pm 8.5$ & $71.8 \pm 10.3$ & $27.5 \pm 3.1$ \\
\hline
\end{tabular}




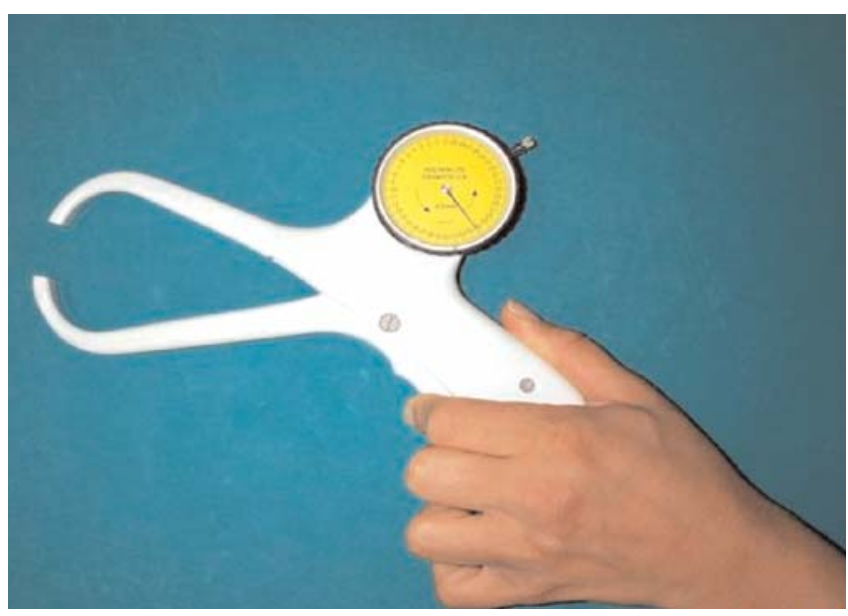

Figure 1. Holtain brand clamp-type mechanical skinfold caliper.

ues assessed by USG, obtained from each of the seven regions of the individual's body are presented in Table 3 .

Measurements made with a skinfold caliper were found significantly higher than those using USG $(\mathrm{p}<0.01)$. When measurements obtained from the same area with the same method were compared among genders, measurements taken from females were found to be higher than those taken from males. There were no significant difference between genders for subcutaneous fat tissue thickness from the submandibular region performed with USG and from the subscapular region with skinfold caliper ( $>0.05)$; however, the differences were significant for measurements taken from all other regions using both methods ( $\mathrm{p}<0.05)$.

The correlation coefficient values obtained between skinfold thickness measurements taken by skinfold

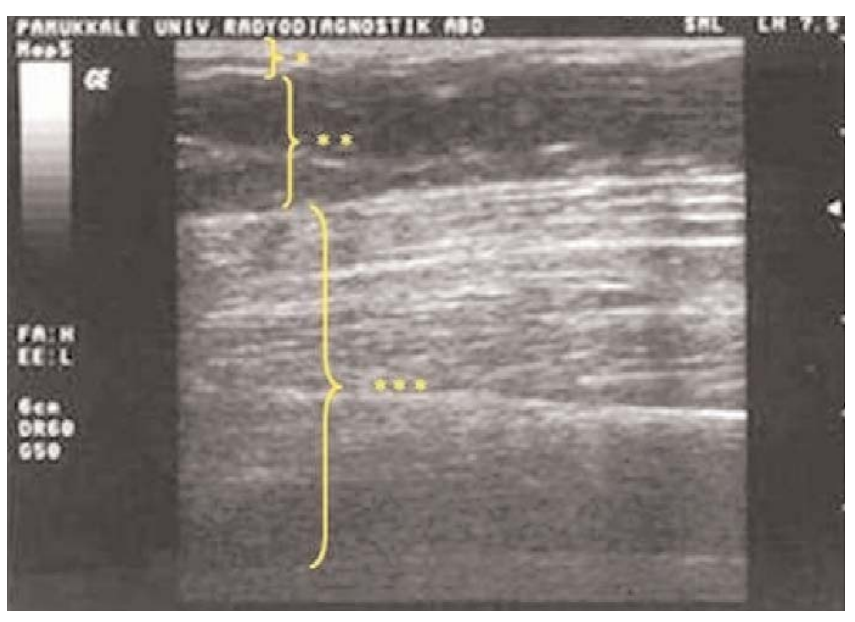

Figure 2. The ultrasound image of subcutaneous fat tissue. *: skin; $* *$ : fat tissue; $* * *$ : muscle tissue.

caliper and subcutaneous fat tissue thickness determined by USG are presented in Table 4, with gender was taken into account. Highly significant correlations were found for measurements from submandibular, triceps, biceps, suprailiac, calf regions, and very high significant correlations were found for measurements from subscapular and thigh regions in males. In females, highly significant correlations were found for measurements from submandibular, triceps, biceps, subscapular, suprailiac, thigh regions, and very high significant correlation was obtained for the measurements taken from the calf region $(\mathrm{p}<0.05)$. The results of measurements conducted for all cases were consistent with the results obtained for genders. The statistically significant positive relationship was found to be valid for measurements taken from all seven regions of the body.

Table 3

Skinfold thickness and subcutaneous fat thickness of the subjects. Measurements are in mm, and using a skinfold caliper and USG.

\begin{tabular}{|c|c|c|c|c|c|c|}
\hline \multirow[b]{2}{*}{ Site } & \multicolumn{2}{|c|}{ Male $(n=50)$} & \multicolumn{2}{|c|}{ Female $(n=50)$} & \multicolumn{2}{|c|}{$\begin{array}{c}\text { Male-Female } \\
\text { Independent samples t-test }\end{array}$} \\
\hline & $\begin{array}{l}\text { Skinfold } \\
\text { Mean } \pm \text { SD }\end{array}$ & $\begin{array}{c}\text { USG) } \\
\text { Mean } \pm \text { SD }\end{array}$ & $\begin{array}{l}\text { Skinfold } \\
\text { Mean } \pm \text { SD }\end{array}$ & $\begin{array}{c}\text { USG } \\
\text { Mean } \pm \text { SD }\end{array}$ & $\underset{p}{\text { Skinfold }}$ & $\begin{array}{l}\text { USG } \\
p\end{array}$ \\
\hline Submandibular & $11.5 \pm 4.3$ & $4.3 \pm 1.2$ & $14.0 \pm 4.6$ & $4.6 \pm 1.2$ & 0.006 & 0.238 \\
\hline Triceps & $11.9 \pm 5.6$ & $5.7 \pm 3.5$ & $20.3 \pm 6.9$ & $13.6 \pm 6.6$ & 0.000 & 0.000 \\
\hline Biceps & $8.2 \pm 3.9$ & $3.4 \pm 1.4$ & $15.2 \pm 6.0$ & $6.6 \pm 3.5$ & 0.000 & 0.000 \\
\hline Subscapular & $19.3 \pm 7.6$ & $5.1 \pm 3.8$ & $21.8 \pm 8.4$ & $7.5 \pm 5.1$ & 0.121 & 0.009 \\
\hline Suprailiac & $12.5 \pm 6.7$ & $7.6 \pm 4.2$ & $18.7 \pm 7.3$ & $14.0 \pm 8.1$ & 0.000 & 0.000 \\
\hline Thigh & $19.5 \pm 8.9$ & $7.3 \pm 3.9$ & $30.3 \pm 8.2$ & $15.0 \pm 6.8$ & 0.000 & 0.000 \\
\hline Calf & $12.6 \pm 6.3$ & $5.5 \pm 2.8$ & $22.2 \pm 7.7$ & $11.1 \pm 4.5$ & 0.000 & 0.000 \\
\hline
\end{tabular}




\section{Discussion}

There are studies in literature which show that skinfold thickness values obtained from different parts of the body are appropriate for use in determining body composition. ${ }^{[3,4,10]}$ The identification of methods for determining body composition, which are proven to be easily applicable, low in cost and reliable, enables body composition to be easily evaluated in clinical settings and to be studied in large groups outside the clinical setting. ${ }^{[11]}$ The measurement of skinfold thickness is one of these methods. Subcutaneous fat tissue comprises $50 \%$ of total amount of body fat. According to this fact, information about body composition may be obtained by measuring skinfold thickness. ${ }^{[4]}$ One such study with this aim was carried out by Belbrauet et al. ${ }^{[12]}$ for evaluating the patient's nutritional status. In this study, triceps skinfold thickness was measured in patients and healthy individuals. Triceps skinfold thickness was observed to be significantly correlated to age in both patients and healthy individuals $(\mathrm{r}=-0.24)$.

In another study from United States, skinfold thickness measurements from the subscapular and triceps regions were made to determine reference curves of subscapular and triceps skinfold thicknesses, for the identification of obesity among children and adolescents. According to the results of the latter study, the mean subscapular skinfold thickness values were similar for black and white children of both genders within the same age range. Among male children within the age range of 8-14, the mean triceps skinfold thickness values were higher in white children when compared to black children. ${ }^{[13]}$ Similar to these, other researchers also determined body composition by making use of skinfold thickness measures. ${ }^{[14-16]}$
Table 4

Correlation of subcutaneous fat thickness between the measurements determined by caliper and ultrasound imaging, in male, female and all subjects $\left({ }^{*} p<0.05\right)$.

\begin{tabular}{lccc}
\hline & \multicolumn{3}{c}{ Correlation coefficient $(\mathbf{r})$} \\
\cline { 2 - 4 } Site & $\begin{array}{c}\text { Male } \\
(\mathbf{n}=50)\end{array}$ & $\begin{array}{c}\text { Female } \\
(\mathbf{n}=50)\end{array}$ & $\begin{array}{c}\text { Total } \\
(\mathbf{n}=100)\end{array}$ \\
\hline Submandibular & $0.586^{*}$ & $0.592^{*}$ & $0.587^{*}$ \\
Triceps & $0.494^{*}$ & $0.703^{*}$ & $0.619^{*}$ \\
Biceps & $0.677^{*}$ & $0.659^{*}$ & $0.636^{*}$ \\
Subscapular & $0.755^{*}$ & $0.641^{*}$ & $0.651^{*}$ \\
Suprailiac & 0.667 & $0.660^{*}$ & $0.607^{*}$ \\
Thigh & $0.763^{*}$ & $0.741^{*}$ & $0.711^{*}$ \\
Calf & $0.740^{*}$ & $0.800^{*}$ & $0.772^{*}$ \\
\hline
\end{tabular}

There are also studies in literature that investigated whether the measured values are valid measures of subcutaneous fat tissue, and thus provide correct information on body composition. The results of the present study investigating the reliability of skinfold thickness measurements are presented in Table 5, together with the results of earlier studies by Weits et al., ${ }^{[17]}$ Fanelli and Kuczmarski, ${ }^{[18]}$ Kuczmarski et al. ${ }^{[19]}$ The results found by Weits et al., ${ }^{[17]}$ Fanelli and Kuczmarski ${ }^{[18]}$ were lower than those found in our study, with the exception of the results of Weits et al. ${ }^{[17]}$ for the measurement of the skinfold of suprailiac region. Fanelli and Kuczmarski ${ }^{[18]}$ also found that the values in the same way in all regions appears to be lower than those in our study. However, the measurements by Kuczmarski et al. ${ }^{[19]}$ were higher than those in our study. These differences may be due to use of different reference points, or due to different racial characteristics of volunteers or the very various

Table 5

Skinfold thickness and subcutaneous fat thickness measurements from the present study and previous studies. Measurements are in $\mathrm{mm}$, and using a skinfold caliper and USG.

\begin{tabular}{|c|c|c|c|c|c|c|c|c|}
\hline \multirow[b]{2}{*}{ Site } & \multicolumn{2}{|c|}{$\begin{array}{l}\text { Present study } \\
\quad(n=100)\end{array}$} & \multicolumn{2}{|c|}{$\begin{array}{l}\text { Weits et al. (1986) } \\
\qquad(n=26)\end{array}$} & \multicolumn{2}{|c|}{$\begin{array}{l}\text { Fanelli and Kuczmarski (1984) } \\
\qquad(n=124)\end{array}$} & \multicolumn{2}{|c|}{$\begin{array}{l}\text { Kuczmarski et al. (1987) } \\
\qquad(n=44)\end{array}$} \\
\hline & Caliper & USG & Caliper & USG & Caliper & USG & Caliper & USG \\
\hline Submandibular & $12.7 \pm 4.6$ & $4.4 \pm 1.2$ & - & - & - & - & - & - \\
\hline Triceps & $16.1 \pm 7.5$ & $9.7 \pm 6.6$ & $11.85 \pm 5.93$ & $8.07 \pm 2.29$ & $10.1 \pm 4.1$ & $6.1 \pm 2.5$ & $30.4 \pm 8.5$ & $20.2 \pm 7.8$ \\
\hline Biceps & $11.7 \pm 6.2$ & $5.0 \pm 3.1$ & $5.40 \pm 2.65$ & $5.35 \pm 1.52$ & $3.6 \pm 1.4$ & $2.4 \pm 1.2$ & $21.3 \pm 7.2$ & $17.2 \pm 7.0$ \\
\hline Subscapular & $20.6 \pm 8.1$ & $6.3 \pm 4.7$ & $12.67 \pm 7.43$ & $8.93 \pm 2.65$ & $10.5 \pm 2.8$ & $5.6 \pm 1.8$ & $27.6 \pm 7.7$ & $14.4 \pm 3.8$ \\
\hline Suprailiac & $15.6 \pm 7.7$ & $10.8 \pm 7.2$ & $19.85 \pm 11.30$ & $7.96 \pm 6.67$ & $15.1 \pm 6.7$ & $8.1 \pm 3.8$ & $33.8 \pm 7.6$ & $29.0 \pm 6.0$ \\
\hline Thigh & $24.9 \pm 10.1$ & $11.2 \pm 6.8$ & - & - & $11.4 \pm 5.1$ & $6.0 \pm 2.1$ & $38.0 \pm 12.8$ & $22.7 \pm 8.7$ \\
\hline Calf & $17.5 \pm 8.5$ & $8.3 \pm 4.7$ & $12.63 \pm 6.12$ & $8.98 \pm 3.16$ & $8.9 \pm 3.8$ & $5.1 \pm 1.8$ & - & - \\
\hline
\end{tabular}


numbers of people participating in these studies. A statistically significant correlation was found between measurements made with skinfold caliper and USG. The measurements obtained using a caliper are higher than those obtained using USG. The cause of this discrepancy is that in measurements conducted by USG only, the thickness of subcutaneous fat tissue is evaluated, whereas in measurements conducted by caliper a double layer of skin is also measured together with subcutaneous fat tissue.

In the studies by Weits et al., ${ }^{[17]}$ Fanelli and Kuczmarski. ${ }^{[18]}$ and Kuczmarski et al., ${ }^{[19]}$ the correlations between measures taken by the two methods are found to be very high and significant in some regions of the body, and high and significant in some other regions.

In the present study, the correlation values between the two methods were calculated to be moderate and significant in the submandibular and subscapular regions, high and significant in the suprailiac region, and very high and significant in the triceps, biceps, thigh and calf regions.

\section{Conclusion}

When USG measurements are taken as reference values for the assessment of actual thickness of subcutaneous fat tissue, skinfold thickness measurements performed with skinfold calipers are found to yield to reliable results. Therefore, accurate assessment of body composition can be carried out by measuring skinfold thickness using a skinfold caliper. In cases where the determination of body composition is important as in obesity screening research, the method of measuring skinfold thickness is a non-invasive and cheap method, and its application is easy. This method may be used within the clinic and outside the clinical settings.

\section{References}

1. De Onis M, Habicht JP. Anthropometric reference data for international use: Recommendations from a WHO Expert Committee. Am J Clin Nutr 1996;64:650-8.

2. Hughes VA, Roubenoff R, Wood M, Frontera WR, Evans WJ, Fiatarone Singh MA. Anthropometric assessment of 10-y changes in body composition in the elderly. Am J Clin Nutr 2004;80: $475-82$.
3. Lukaski HC. Methods for the assessment of human body composition: traditional and new. Am J Clin Nutr 1987;46:537-56.

4. Tamer K. Sporda fiziksel-fizyolojik performansın ölçülmesi ve değerlendirilmesi. Ankara: Bağırgan Yayınevi; 2000.

5. Oyar O. Radyolojide temel fizik kavramlar. İstanbul: Nobel Tip Kitabevleri; 1998.

6. Sato S, Demura S. Regional subcutaneous fat characteristics stratified by sex, age, and obesity, and their relationships with total and visceral fat in a japanese population. J Physiol Anthropol 2009;28: 231-8.

7. Holzhauer S, Zwijsen R, Jaddoe V, et al. Sonographic assessment of abdominal fat distribution in infancy. Eur J Epidemiol 2009;24: 521-9.

8. Viskovic K, Richman I, Klasnic K, et al. assessment of ultrasound for use in detecting lipoatrophy in HIV-infected patients taking combination antiretroviral therapy. AIDS Patient Care STDS 2009;23:79-84.

9. Abe T, Sakurai T, Kurata J, et al. Subcutaneous and visceral fat distribution and daily physical activity:comparison between young and middle aged women. Br J Sports Med 1996;30:297-300.

10. Atalay A, Hasçelik HZ. Obezite. Hacettepe Tıp Dergisi 2000;31: 320-9.

11. Bray GA. Obesity. In: Fauci AS, Braunwald E, Isselbacher KJ, et al., eds. Harrison's principles of internal medicine. 14th ed. New York: McGraw-Hill; 1998. p.454-9.

12. Belbraouet S, Chau N, Tebi A and Debry G. Anthropometric characteristics of hospitalised elderly women: A case-control study Int J Environ Res Public Health 2011;8:2584-92.

13. Addo OY, Himes JH. Reference curves for triceps and subscapular skinfold thicknesses in US children and adolescents. Am J Clin Nutr 2010;91:635-42.

14. Durnin JVGA, Womersley J. Body fat assessed from total body density and its estimation from skinfold thickness: measurements on 481 men and women aged from 16 to 72 years. Br J Nutr 1974; 32:77-97.

15. Lohman TG. Skinfolds and body density and their relation to body fatness. Hum Biol 1981;53:181-225.

16. Ramirez ME. Subcutaneous fat distribution in adolescents. Hum Biol 1993;65:771-82.

17. Weits T, Van Der Beek EJ, Wedel M. Comparison of ultrasound and skinfold caliper measurement of subcutaneous fat tissue. Int $\mathrm{J}$ Obes 1986;10:161-8.

18. Fanelli MT, Kuczmarski RJ. Ultrasound as an approach to assessing body composition. Am J Clin Nutr 1984;39:703-9.

19. Kuczmarski RJ, Fanelli MT, Koch GG. Ultrasonic assessment of body composition in obese adults: overcoming the limitations of the skinfold caliper. Am J Clin Nutr 1987;45:717-24.

\author{
Correspondence to: Dr. Şahika Pınar Akyer \\ Department of Anatomy, Faculty of Medicine, \\ Pamukkale University, Denizli, Turkey \\ Phone: +90 2582961670 \\ e-mail: spakyer@pau.edu.tr \\ Conflict of interest statement: No conflicts declared.
}

